\title{
Practical Development of Non-performing Assets Securitization In China and Other Countries
}

\author{
Ang Li \\ School of Software and Microelectronics \\ Peking University \\ Beijing, China \\ charleslipku@gmail.com
}

\author{
Meng Liu \\ School of International Education \\ Henan University \\ Kaifeng, China \\ Serendipity10@126.com
}

\begin{abstract}
From 1970s, there are always financial crisis over the world, brings a lot of uncertainties to the economy development of every country, especially the increases risks of commercial banks. These unstable economy situations result in the weakness of financial structure, so that commercial banks no matter in developing countries and developed countries have trouble with non-performing assets problems. Based on the review of practical development of non-performing assets securitization in foreign countries, this paper elaborated the process of Chines non-performing assets securitization, and analyzed the necessity of that for China.
\end{abstract}

Keywords-non-performing assets; asset securitization; commercial banks

\section{INTRODUCTION}

Assets securitization is created under unfavorable operating environment and increased risk of a credit situation [1]. The following factors contributed to the development of asset securitization.

\section{A. Dramatic changes of international economic environment}

From early 1970s, international economic environment have a series of dramatic changes, including a sharp change of interest rate and exchange rate, oil crisis, the international debt crisis and so on. Undoubtedly, these changes led to increase management risks of each economic unit.

The commercial banks mainly issue housing mortgage loans, which are usually long-term and fixed interest rate, but the dramatic change of interest rate and exchange rate have a great effect on these commercial banks.

In some extent, oil crisis led to the decline of assets of commercial banks, because oil crisis increased the cost of petroleum import, as a result, the operational environment of enterprise became bad.

Finally, the dramatic change of interest rate and exchange rate and oil crisis contributed to the international debt crisis [2]. The main reason is that development of developing countries' economy slowed down, they could not pay off debts, so that some commercial banks had a large amount of non-performing assets, reducing the liquidity and increasing operational risks.

\section{B. Financial deregulation}

From 1980s, the developed countries relaxed financial controls, and most countries involved in boosting the process of financial liberalization. The financial deregulation provided more space for financial institutions, financial market and financial innovation. The financial deregulation stimulated a crowd of financial products, for example, some financial derivatives and other financial tools, providing the necessary prerequisites for assets securitization [3].

\section{Development of information technology}

With the increasing uncertainty factors, the increasing risks and financial deregulation, based on new financial theory, many innovative financial products had been created through utilizing new formation technology, which guaranteed the development of assets securitization.

Known for its delicate design and unique function, assets securitization has been one of the most remarkable financial innovations [4]. In Chinese financial market, commercial banks with a large amount of non-performing assets is one of the biggest barrier for Chinese financial reformation. The government has allowed commercial banks carry on shareholding reform. With the development of reform, disposing non-performing assets becomes more urgent.

Non-performing assets is a big burden for commercial banks, because its unique economic function and social status, it not only leads to the increase of operational cost of commercial banks, but also for the whole society.

In China, commercial banks' assets include reserve assets, external assets and various debts. Chinese undeveloped capital market is restricted by Chinese economic environment and commercial bank operational system. As result, Chinese capital market structure is over simple, focused on the loan, Chinese commercial banks' non-performing assets mainly include non-performing loan, and they are considered equal in some extent.

In recent years, the amount and proportion of commercial banks' non-performing assets are both keep declining, according to the latest data reported by China Banking Regulatory Commission, by the end of first quarter of 2013, the total amount of commercial banks' nonperforming loan is 51.8 billion RMB, increased by $6.8 \%$ compared with that of the previous quarter, and the nonperforming loan ratio increased to $0.96 \%$ [5]. Recovery rate of non-performing assets of China's financial system remains at around $21 \%$, in spite of the increase of recovery rate recently, but it is still lower than that of Korea, Singapore other Asian countries. 
At present, Chinese banking industry is in rapid development stage, the assets are expanding fast. So in the process of increasing the supply of credit at a high speed, non-performing loan is likely to rise. As a result, it is meaningful to study practical development of nonperforming assets securitization from foreign countries in practice and theory.

\section{PRACTICAL DEVELOPMENT OF NON-PERFORMING ASSETS SECURITIZATION IN FOREIGN COUNTRIES}

\section{A. US}

Asset securitization originated in the mortgage market of the United States in the late 1960s. In the end of 1980s, for the sake of disposing non-performing assets of savings and loan system, the Resolution Trust Corporation funded by government started the first time for non-performing assets securitization, more than half of the total amount of global issuance. Later, it improved the asset management, deal structure, credit ratings and other aspects of non-performing assets securitization, promoting the development of nonperforming assets securitization greatly [6].

In March 1980, with the cancellation of the financial institutions deposits interest rate in the United States, many small saving bank absorbed a large amount of short-term debts through increasing interest rate, but most of these short-term debts were utilized by real estate and securities and other industries with long-term period and high risks. As a result of risk concentration, bad management, asset liability mismatch and other reasons, many saving banks trapped into crisis. In 1984, there were around 71 insolvent saving banks, the number increased to 130 by 1985 . By the end of 1988, non-performing assets of saving banks in United States was $\$ 74.3$ billion, and the number of insolvent banks increased to 243 .

To resolve the banking crisis, the U.S. government enacted some relevant laws, dealing with non-performing assets of saving banks comprehensively. And the government set up specialized institutions, for example, according to Financial Institutions Reform, Recovery and Implementation Act, the government established the Resolution Trust Corporation specially. Besides some regular methods, some financial innovation were applied to dispose non-performing assets, which helped banks dispose a large amount of non-performing assets and the whole banking industry get rid of crisis.

Now, a wide variety of asset securitizations have been designed in the capital market of the United States, details can be seen from the following figure:

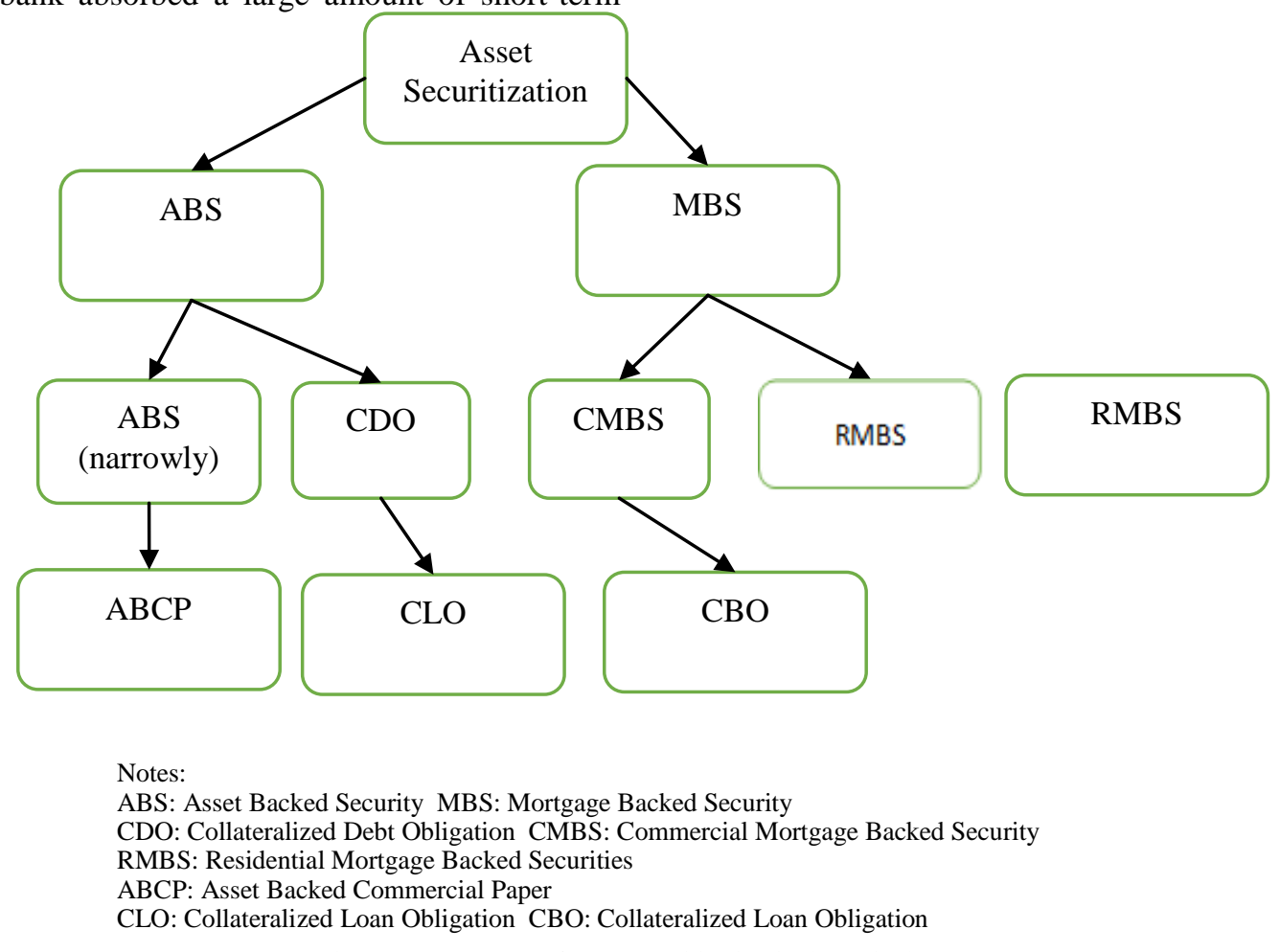

Figure 1. Category of asset securitization in the United States

\section{B. Korea}

In 1997, Asian financial crisis burst, Korean nonperforming asset ratio increased rapidly to $15 \%$ from $0.8 \%$ in 1996. To deal with these non-performing assets and guarantee the successful implement of asset securitization, from 1997, the Korean government enacted several relevant laws, and rebuilt Korea Asset Management Corporation (KMAC). In addition, the government set up two securitization companies overseas, one is Korea First 
Securitization Corporation, the other is called South Korea Asset Fund. Besides legal support, Korea also attaches great importance to staff training, it really has a positive effect on non-performing assets securitization.

It is crucial for Korea to set up Korea Asset Management Corporation to dispose non-performing assets securitization. By the end of 2011, KMAC disposed nonperforming assets up to 58.5 trillion won, among that 8 trillion won non-performing assets was disposed through the securitization, with a recovery rate of $45.98 \%$.

\section{Japan}

The Asian financial crisis in 1997 also had a great negative effect on Japan, and it make the whole country realize the necessity of non-performing assets securitization. After the burst of the bubble economy, non-performing assets of Japanese banks increased dramatically. For adjusting accounting and tax system to deal with these nonperforming assets, the government enacted Special Purpose Vehicle Law and Investment Trust Law.

In 1998, based on Special Purpose Vehicle Law, the Japanese government set up a Special Trade Company, which was similar with the Resolution Trust Corporation of the United States. In April 1999, the Special Trade Company was renamed as Recycling and Cleaning Credit (RCC), with two departments of Credit Price Audit and Business Development. The duty of the former department was to determine the just and reasonable price of credits through employing some authoritative experts to evaluate different debts of enterprises, such as registered accountant and lawyer. And the department of Business Development was responsible for selling out non-performing debt.

In November 1999, Morgan Stanley first launched nonperforming assets securitization of Japan in the Cayman Islands, non-performing assets involved was about 21 billion yen. Henceforth, the RCC securitized a wide range of non-performing assets.

In addition, Taiwan, India and Malaysia have enacted special laws for non-performing assets securitization and showed good performance in practice

\section{NON-PERFORMING ASSETS SECURITIZATION MODES IN THE WORLD}

Currently, there are three main modes of non-performing assets securitization in the world.

The first one is American mode, also known as offbalance sheet business model. It is used to purchase banks' assets and realize the real sale of assets through the SPV outside the bank.

The second is known as German mode, also called inbalance sheet business model. It used for assets securitization by setting up an institution inside the bank, but asset ownership still remains in the bank's balance sheet.

The third one is a combination of the two modes above, that is Australian mode. From the practical development of non-performing assets securitization in the world, Korea, Japan and other countries adopt or follow the American mode.

\section{THE PROCESS OF ATTEMPTING NON-PERFORMING ASSETS SECURITIZATION IN CHINA}

Chinese economy is in the reform stage and nonperforming assets securitization is in early stage, but nonperforming assets securitization is getting more and more importance. The attempt process is moving forward gradually.

In November 2001, China Huarong Asset Management Corporation sold 10.8 billion yuan non-performing assets, and this was the first time for disposing non-performing assets in Chinese history.

In 2003, cooperating with Deutsche Bank, China Cinda Asset Management Corporation attempted to practice nonperforming assets securitization, launched offshore mode. There were 20 projects and 2.5 billion yuan non-performing assets, and the total issuance for foreign investors was around \$1.6 billion. In June 2003, China Huarong Asset Management Corporation dealt with non-performing assets in the form of trust products, but due to the limitations of trust products, it was called prospective asset securitization.

In April 2004, Industrial and Commercial Bank of China (ICBC) launched a securitization, taking 2.6 billion yuan non-performing loans as underlying asset. ICBC entrusted non-performing credits to China Credit Trust CO. LTD.

In October 2004, China Cinda Asset Management Corporation started to cooperate with China International Capital Corporation, and disposed a total amount of 20 billion yuan non-performing assets in the complete asset securitization mode.

According to the data reported by China Banking Regulatory Commission, the amount and ratio of nonperforming loan of Chinese commercial banks saw slight increase as is shown in the following table 
TABLE I. NON-PERFORMING LOAN OF CHINESE COMMERCIAL BANKS IN 2012 (BILLION YUAN)

\begin{tabular}{|c|c|c|c|c|c|c|c|c|}
\hline & \multicolumn{2}{|c|}{$1^{\text {st }}$ Quarter } & \multicolumn{2}{|c|}{$2^{\text {nd }}$ Quarter } & \multirow{2}{*}{$\begin{array}{l}3^{\text {rd }} \\
\text { Quarter } \\
\text { Total }\end{array}$} & \multicolumn{3}{|c|}{$4^{\text {th }}$ Quarter } \\
\hline & Total & Ratio & Total & Ratio & & Ratio & Total & Ratio \\
\hline All commercial banks & 4382 & $0.94 \%$ & 4564 & $0.94 \%$ & 4788 & $0.95 \%$ & 4929 & $0.95 \%$ \\
\hline State-owned commercial banks & 2994 & $1.04 \%$ & 3020 & $1.01 \%$ & 3070 & $1.00 \%$ & 3095 & $0.99 \%$ \\
\hline Joint-equity commercial banks & 608 & $0.63 \%$ & 657 & $0.65 \%$ & 743 & $0.70 \%$ & 797 & $0.72 \%$ \\
\hline Urban commercial banks & 359 & $0.78 \%$ & 403 & $0.82 \%$ & 424 & $0.85 \%$ & 419 & $0.81 \%$ \\
\hline Rural commercial banks & 374 & $1.52 \%$ & 426 & $1.57 \%$ & 487 & $1.65 \%$ & 564 & $1.76 \%$ \\
\hline Foreign banks & 48 & $0.49 \%$ & 58 & $0.58 \%$ & 63 & $0.62 \%$ & 54 & $0.52 \%$ \\
\hline
\end{tabular}

As we can see in the table, by the end of 2012, nonperforming assets of Chinese commercial banks have reached 4929 billion yuan, which is really a huge number. According to American banking evaluation convention, non-performing assets ratio of banks with high-quality assets are usually less than $0.5 \%$, the non-performing assets ratio over $1 \%$ symbols that low quality of bank assets. As a result, it is obvious that Chinese is getting trouble of nonperforming assets, especially the state-owned commercial banks and rural commercial banks.

Therefore, it is the highest priority for Chinese commercial banks to figure out how to utilize asset securitization or other methods to dispose the huge amount of non-performing assets.

\section{REFERENCES}

[1] Yu Fengkun, Asset Securitization: Theory and Pracice[M], Peking University Press, 2002, 7-20

[2] Li Qingyuan, Interest, Market and New Finacial World[M], China Finance Press, 1990, 38-62

[3] Carlstrom, C., Samolyn, K.. Examining the Microfoundations of Market Incentives for Asset Backed Lending [J]. Federal Reserve Bank of Cleveland. Econ. Rev. 1993, 29 (1): 27-38

[4] Diamond, D.. Financial intermediation and delegated monitoring [J]. Rev. Econ. Stud. 1984, 51, 393-414

[5] China Banking Regulatory Commission, http://www.cbrc.gov.cn

[6] Xiong Jinguang, Wu Wenyong, Research of Financial Assets Securitization Legal System [M], Jiang Xi People Press, 2006, 43-69 